\title{
Characteristics of $\mathrm{NaCl}$ and Water Transport
}

\author{
in the Renal Proximal Tubule
}

\author{
Juha P. Kokko, Maurice B. Burg, and Jack Orloff. \\ From the Laboratory of Kidney and Electrolyte Metabolism, National Heart \& Lung \\ Institute, National Institutes of Health, Bethesda, Maryland 20014
}

A B S T R A C T Renal proximal tubular transport of salt and water has been examined using isolated perfused rabbit tubules. In this method direct measurements can be made under controlled conditions not readily achieved in vivo. The results are in general agreement with previous micropuncture studies in other species, supporting the validity of both sets of measurements.

In the present studies, absorption of sodium salts and water occurred without change in the concentration of $\mathrm{Na}$ in the lumen except when a poorly reabsorbed solute (raffinose) was present, in which case, mean concentration of $\mathrm{Na}$ in the lumen reached a steady-state value $33-35 \mathrm{mEq}$ liter ${ }^{-1}$ less than in the bath. The tubule is very permeable to sodium salts (sodium permeability $=9.3 \times 10^{-5} \mathrm{~cm} \mathrm{sec}{ }^{-1}, \quad \sigma_{\mathrm{NaCl}}=0.68-$ $(0.71)$ and to water (hydraulic conductivity $\left[\mathrm{L}_{\mathrm{p}}\right]$ $=2.9$ to $6.3 \times 10^{-5} \mathrm{~cm} \mathrm{sec}^{-1} \mathrm{~atm}^{-1}$ ). Net reabsorptive flux of $\mathrm{Na}$ was only $20 \%$ of the unidirectional $\mathrm{Na}$ flux.

The steady-state concentration difference for $\mathrm{Na}$ in the presence of raffinose and $\sigma_{\mathrm{NaCl}}$ in the present studies was the same as previously found by micropuncture in the rat. On the other hand $\mathrm{Na}$ permeability, net $\mathrm{Na}$ transport rate, and $L_{p}$ were all from one-half to onethird as great in the isolated rabbit tubule as in the rat in vivo. Apparently, although the transport mechanisms appear to be basically the same in the two species, there are fewer transport units and passive permeability paths per unit length in the rabbit tubule than in the rat.

\section{INTRODUCTION}

Walker, Bott, Oliver, and MacDowell (1) were the first to report that the glomerular filtrate is reduced in volume in the proximal convoluted tubule of rat and

Dr. Kokko's present address is the Department of Medicine, Southwestern Medical School, University of Texas, Dallas, Texas 75235.

Received for publication 11 June 1970. guinea pig without a change in the osmolality of the tubule fluid. Their micropuncture results have been repeatedly confirmed and extended to other species (2). In addition it has been established that the concentration of $\mathrm{Na}$ in tubule fluid remains equal to that of plasma during the reabsorptive process unless osmotic flow is restricted by inclusion of a poorly absorbed solute in the luminal fluid (2).

The present experiments were designed to re-examine the reabsorptive mechanism for $\mathrm{Na}$ and water in the isolated perfused rabbit proximal convoluted tubule. The system employed permits direct estimates, under controlled conditions not readily achieved in the in vivo preparation, of a number of phenomenological coefficients necessary for characterization of the tubule epithelium. It has been possible to measure the passive permeability of the epithelium to $\mathrm{Na}$, the rate of active $\mathrm{Na}$ transport, the hydraulic conductivity of the epithelium to water, and the reflection coefficient for $\mathrm{NaCl}$. The results are in large part similar to those obtained in vivo and have been interpreted within the framework of current views of the mechanims of fluid reabsorption by the proximal tubule of the mammal.

\section{METHODS}

Rabbit proximal convoluted tubules were dissected and perfused in vitro using a modification of a method previously described $(3,4)$, as summarized below.

New Zealand white female rabbits were injected intravenously with $10 \mathrm{cc}$ of $15 \%$ solution of mannitol ${ }^{1}$ and were killed by decapitation $10 \mathrm{~min}$ later. A piece of the right kidney was removed and placed in chilled rabbit serum for dissection. A superficial proximal convoluted tubule was dissected free and transferred to a separate dish where it was perfused while

\footnotetext{
1 The purpose of mannitol was to slow collapse of the tubule thus facilitating subsequent perfusion. It was later found that perfusion could be successfully initiated even in fully collapsed tubules. Consequently the use of mannitol was discontinued midway through the experiments without any apparent change in the results.
} 
TABLE I

Sodium Flux and Permeability of Isolated Perfused Proximal Convoluted Tubules

\begin{tabular}{|c|c|c|c|c|c|c|c|c|c|c|c|c|c|}
\hline \multirow[b]{2}{*}{ Bath } & \multirow[b]{2}{*}{ Perfusate } & \multirow[b]{2}{*}{$\begin{array}{l}\text { Perfu- } \\
\text { sion } \\
\text { rate } \\
(\mathrm{Vo})\end{array}$} & \multirow[b]{2}{*}{$\begin{array}{l}\text { Collec- } \\
\text { tion } \\
\text { rate } \\
\left(V_{L}\right)\end{array}$} & \multirow[b]{2}{*}{$\begin{array}{l}\text { Lumi- } \\
\text { nal } \\
\text { area } \\
\text { (A) }\end{array}$} & \multicolumn{3}{|c|}{$\mathrm{Na}$ concentration } & & \multirow[b]{2}{*}{$\begin{array}{l}\text { Net } \\
\text { vol } \\
\text { flux } \\
\left(J_{v}\right)\end{array}$} & \multirow{2}{*}{$\begin{array}{c}\mathrm{Net} \\
\mathrm{Na} \\
\text { flux } \\
\left(\mathrm{MNa}_{\mathrm{a}}\right)\end{array}$} & \multirow{2}{*}{$\begin{array}{c}\mathrm{Na} \\
\text { flux } \\
\text { lumen } \\
\text { to } \\
\text { bath } \\
\left(\mathrm{MN}_{\mathrm{a}_{1 \rightarrow} \rightarrow^{\prime}}\right)\end{array}$} & \multirow{2}{*}{$\begin{array}{c}\mathrm{Na} \\
\text { permea- } \\
\text { bility } \\
\text { bath } \\
\text { to } \\
\text { lumen } \\
\left(\mathrm{PN}_{\mathbf{a}_{\mathrm{b} \rightarrow 1}}\right)\end{array}$} \\
\hline & & & & & $\begin{array}{r}\text { Bath } \\
{[\mathrm{Na}]_{b}}\end{array}$ & $\begin{array}{c}\text { Per- } \\
\text { fused } \\
{[\mathrm{Na}] \mathrm{o}}\end{array}$ & $\begin{array}{c}\text { Col- } \\
\text { lected } \\
{[\mathrm{Na}]_{\mathbf{L}}}\end{array}$ & $\frac{\left[\mathrm{Na}^{22}\right]_{\mathrm{o}}}{\left[\mathrm{Na}^{22}\right] \mathrm{L}}$ & $\frac{\left[\mathrm{Na}^{24}\right]_{\mathrm{L}}}{\left[\mathrm{Na}^{24}\right]_{\mathrm{b}}}$ & & & & \\
\hline & & $\mathrm{cm}^{3} \mathrm{sec}^{-1}$ & $\times 10^{-9}$ & $\begin{array}{c}\mathrm{cm}^{2} \\
\times 10^{-4}\end{array}$ & & $\mathrm{~cm}^{-3} \times$ & & & & $\begin{array}{c}c m \sec ^{-1} \\
\times 10^{-5}\end{array}$ & $\begin{array}{c}E q \mathrm{~cm}^{-2} \\
\mathrm{sec}^{-1} \\
\times 10^{-9}\end{array}$ & $\begin{array}{c}E q \mathrm{~cm}^{-2} \\
\mathrm{sec}^{-1} \\
\times 10^{-9}\end{array}$ & $\begin{array}{c}\mathrm{cm} \mathrm{sec}-1 \\
\times 10^{-5}\end{array}$ \\
\hline \multirow[t]{6}{*}{ Serum } & Ultrafiltrate & 417 & 385 & 5.34 & 155 & 145 & 150 & 1.13 & & 5.99 & 5.08 & 22.5 & 11.2 \\
\hline & & 422 & 405 & 5.02 & 154 & 145 & 147 & 1.16 & & 3.39 & 3.30 & 22.8 & 12.7 \\
\hline & & 332 & 326 & 7.22 & 146 & 147 & 142 & 1.13 & & 0.83 & 3.47 & 9.3 & 4.0 \\
\hline & & 212 & 190 & 7.54 & 148 & 147 & 140 & 1.53 & & 2.91 & 6.04 & 20.3 & 9.6 \\
\hline & & 342 & 313 & 7.40 & 155 & 145 & 148 & 1.35 & & 3.92 & 4.42 & 25.1 & 13.3 \\
\hline & Mean & & & & 152 & 146 & 145 & & & 3.41 & 4.46 & 20.0 & 10.2 \\
\hline \multirow[t]{7}{*}{ Serum } & Ultrafiltrate & 208 & 207 & 5.15 & 143 & 114 & 110 & 1.48 & & 0.19 & 1.82 & 17.9 & 11.2 \\
\hline & +raffinose & 320 & 280 & 5.65 & 144 & 114 & 120 & 1.28 & & 7.07 & 5.10 & 23.6 & 12.8 \\
\hline & (isosmotic) & 348 & 371 & 6.15 & 150 & 114 & 109 & 1.22 & & -3.74 & -1.24 & 8.8 & 6.7 \\
\hline & & 275 & 294 & 6.59 & 147 & 114 & 108 & 1.59 & & -2.88 & -0.61 & 18.9 & 13.3 \\
\hline & & 233 & 249 & 5.65 & 143 & 116 & 106 & 1.35 & & -2.83 & 1.12 & 11.2 & 7.0 \\
\hline & & 379 & 362 & 6.28 & 145 & 116 & 107 & 1.21 & & 2.71 & 8.32 & 15.5 & 5.0 \\
\hline & Mean & & & & 145 & 114 & 110 & & & 0.09 & 2.41 & 16.0 & 9.3 \\
\hline Serum & Raffinose & 172 & 172 & 5.34 & 205 & & 48 & & 0.234 & 0 & -15.5 & & 9.2 \\
\hline \multirow[t]{6}{*}{$+\mathrm{NaCl}$} & & 133 & 112 & 5.15 & 201 & & 33 & & 0.164 & 4.08 & -7.18 & & 5.2 \\
\hline & & 255 & 240 & 8.80 & 205 & & .37 & & 0.180 & 1.70 & -10.1 & & 6.4 \\
\hline & & 178 & 168 & 5.65 & 211 & & 40 & & 0.190 & 1.77 & -11.9 & & 7.3 \\
\hline & & 184 & 187 & 10.1 & 206 & & 48 & & 0.230 & -0.30 & -8.89 & & 6.0 \\
\hline & & 103 & 110 & 6.28 & 211 & & 68 & & 0.322 & -1.43 & -11.9 & . & 8.0 \\
\hline & Mean & & & & 207 & & 46 & & & 0.97 & -10.9 & & 7.0 \\
\hline
\end{tabular}

observed with either an inverted microscope at a magnification of $50-400$ or a dissecting microscope at a magnification of 6-100. During perfusion the tubules were bathed in rabbit serum bubbled with $95 \% 0_{2}-5 \% \mathrm{CO}_{2}$ at $37^{\circ} \mathrm{C}$. The following three perfusion solutions were used: $(a)$ an ultrafiltrate of the same lot of serum as that used in the bath (prepared with Amicon PM-10 membranes), (b) a raffinose solution containing $0.001 \mathrm{M} \mathrm{MgSO}, 0.001 \mathrm{CaCl}_{2}$, and $0.0025 \mathrm{~K}_{2} \mathrm{HPO}_{4}$, and (c) a mixture of $(a)$ and (b). Solutions containing raffinose were adjusted to $\mathrm{pH} 7.4$ and to the same osmolality as the bath. The osmolality of the serum was lowered to equal that of the ultrafiltrate by addition of an appropriate amount of water. No adjustment was made to equalize the concentration of $\mathrm{Na}$ in plasma and ultrafiltrate, the former being higher (Table I) owing to the presence of protein. The bathing solution was exchanged with fresh medium every 10-20 min in all experiments with the exception of those in which ${ }^{24} \mathrm{Na}$ was included in the bath. In these water was added to the bath every $10 \mathrm{~min}$ in amounts sufficient to correct for evaporative loss.

The fluid in the collecting pipet holding the tubule was covered with mineral oil to prevent evaporation. In addition when the $\mathrm{Na}^{+}$permeability of the tubule was measured, the tubule was sealed into the collecting pipet with Sylgard 184 (5). This was done to avoid any isotopic exchange of $\mathrm{Na}$ in collected fluid with that in the bath by diffusion through a potential space between the outer surface of the tubule and the inner surface of the pipet. The collected fluid was removed at timed intervals, and its volume was measured in a calibrated glass capillary.
In order to permit calculation of net fluid transport either albumin ${ }^{125} \mathrm{I}$ or ${ }^{131} \mathrm{I}$ was added to the perfusate, and the concentration of isotope was measured in both the perfusate and the collected fluid. In studies designed to determine the $\mathrm{Na}$ concentration of the collected fluid and the permeability of the tubule to $\mathrm{Na},{ }^{22} \mathrm{Na}$ was added to the perfusate and ${ }^{24} \mathrm{Na}$ to the bath. The $\mathrm{Na}$ concentration in the perfusate ([Na]o) and bath $\left([\mathrm{Na}]_{b}\right)$ and the radioactivity of the perfusate $\left(\left[{ }^{22} \mathrm{Na}\right]_{\mathrm{o}}\right)$ and bath $\left(\left[{ }^{24} \mathrm{Na}\right]_{\mathrm{b}}\right)$ were measured, as well as the radioactivity $\left(\left[{ }^{22} \mathrm{Na}\right]_{\mathrm{L}}\right.$ and $\left.\left[{ }^{24} \mathrm{Na}\right]_{\mathrm{L}}\right)$ in the collected perfusion fluid. The $\mathrm{Na}$ concentration in the collected fluid, $[\mathrm{Na}]_{\mathrm{L}}$, is the sum of that $\mathrm{Na}$ originating from the perfusion fluid, $\left[\mathrm{Na}^{\prime}\right]_{\mathrm{L}}$, and from the bath $\left[\mathrm{Na}^{\prime \prime}\right]_{\mathrm{L}}$ (vide infra). Thus, $[\mathrm{Na}]_{\mathrm{L}}$ $=\left[\mathrm{Na}^{\prime}\right]_{\mathrm{L}}+\left[\mathrm{Na}^{\prime \prime}\right]_{\mathrm{L}}$. Assuming that ${ }^{24} \mathrm{Na}$ and ${ }^{22} \mathrm{Na}$ are perfect tracers,

$$
\frac{\left[\mathrm{Na}^{\prime}\right]_{\mathrm{L}}}{\left[{ }^{22} \mathrm{Na}\right]_{\mathrm{L}}}=\frac{[\mathrm{Na}]_{\mathrm{o}}}{\left[{ }^{22} \mathrm{Na}\right]_{\mathrm{o}}}
$$

and

$$
\frac{\left[\mathrm{Na}^{\prime \prime}\right]_{\mathrm{L}}}{\left[{ }^{24} \mathrm{Na}\right]_{\mathrm{L}}}=\frac{[\mathrm{Na}]_{\mathrm{b}}}{\left[{ }^{24} \mathrm{Na}\right]_{\mathrm{b}}}
$$

Combining these equations and rearranging,

$$
[\mathrm{Na}]_{\mathrm{L}}=\frac{\left[{ }^{22} \mathrm{Na}\right]_{\mathrm{L}}[\mathrm{Na}]_{\mathrm{o}}}{\left[{ }^{22} \mathrm{Na}\right]_{\mathrm{o}}}+\frac{\left[{ }^{24} \mathrm{Na}\right]_{\mathrm{L}}[\mathrm{Na}]_{\mathrm{b}}}{\left[{ }^{24} \mathrm{Na}\right]_{\mathrm{b}}}
$$

The above method for the determination of the concentration of $\mathrm{Na}$ would yield erroneous, results were the specific activity of the tubule fluid appreciably affected by unlabeled $\mathrm{Na}$ originating in the cells. This is not a source of error in the 
current studies since little $\mathrm{Na}$ (relative to that in lumen and bath) is present in tubule cells, and in addition cellular exchange is so rapid (6) that intracellular $\mathrm{Na}$ is completely labeled by the time the experimental collections are begun (i.e. more than $5 \mathrm{~min}$ after placement of the tubule in the radioactive solutions). The radioactivity of each isotope was determined in a three-channel well scintillation counter (Packard 3003). ${ }^{24} \mathrm{Na}$ was counted immediately at the completion of the study and again 14 days later at which time it had decayed. ${ }^{22} \mathrm{Na}$ and ${ }^{125} \mathrm{I}$ were determined only on the 14 day sample. The osmolality of the collected perfusion fluids was measured using the method of Ramsay and Brown (7). Perf usate and bath osmolality were measured with a BowmanAminco osmometer. The concentrations of $\mathrm{Na}$ in the perfusate and bathing solution were measured with an IL flame photometer (Instrumentation Laboratory, Inc., Watertown, Mass.) and $\mathrm{pH}$ with a Beckman expanded scale $\mathrm{pH}$ meter.

The sources of radioisotopes were: ${ }^{125} \mathrm{I}, \mathrm{E}$. R. Squibb \& Sons, New York; ${ }^{24} \mathrm{Na}$, International Nuclear Corporation; ${ }^{22} \mathrm{Na}$, New England Nuclear Corp., Boston, Mass.; ${ }^{131} \mathrm{I}$, Abbott Laboratories, North Chicago, Ill.

Calculation of fluxes and permeabilities. Net Na flux $\left(\mathrm{M}_{\mathrm{Na}}\right)$ was calculated from the relationship

$$
M_{N a}=\frac{V_{o}[\mathrm{Na}]_{0}-V_{L}[\mathrm{Na}]_{L}}{A}
$$

where $V_{O}$ is the perfusion rate, $V_{L}$ the rate of flow into the collecting pipet, and $\mathrm{A}$ the surface area of the tubule.

Unidirectional $\mathrm{Na}$ flux from lumen to bath $\left(\mathrm{M}_{\mathrm{Na}_{1 \rightarrow b} \mathrm{~b}}\right)$ was calculated from the relationship $\mathrm{M}_{\mathrm{Na}_{1 \rightarrow b}}=\mathrm{P}_{\mathrm{Na}_{1 \rightarrow b}}([\mathrm{Na}] \mathrm{o}$ $\left.+[\mathrm{Na}]_{\mathrm{L}}\right) / 2$, where $\mathrm{P}_{\mathrm{Na}_{1 \rightarrow b} \mathrm{~b}}$ is the $\mathrm{Na}$ permeability from lumen to bath and $\left([\mathrm{Na}]_{0}+[\mathrm{Na}]_{\mathrm{L}}\right) / 2$ is the mean concentration of $\mathrm{Na}$ in the tubule lumen. $\mathrm{P}_{\mathrm{Na}_{1 \rightarrow b}}$ was determined as previously described (8) where

$$
\mathrm{P}_{\mathrm{Na}_{1 \rightarrow b}}=\frac{\mathrm{V}_{\mathrm{O}}-\mathrm{V}_{\mathrm{L}}}{\mathrm{A}}\left[\frac{\ln \left(\left[{ }^{22} \mathrm{Na}\right]_{\mathrm{O}} /\left[{ }^{22} \mathrm{Na}_{\mathrm{L}}\right)\right.}{\ln \left(\mathrm{V}_{\mathrm{O}} / \mathrm{V}_{\mathrm{L}}\right)}+1\right]
$$

In the experiments in which these calculations were used (Table I, top and middle) $[\mathrm{Na}]_{\mathrm{o}}$ was similar to $[\mathrm{Na}]_{\mathrm{L}}$, so that $\left([\mathrm{Na}]_{0}+[\mathrm{Na}]_{\mathrm{L}}\right) / 2$ is an adequate approximation of the mean concentration of $\mathrm{Na}$ in the tubule lumen.

$\mathrm{Na}$ permeability from bath to lumen $\left(\mathrm{P}_{\left.\mathrm{Nab}_{1}\right)}\right)$ in experiments in which ultrafiltrate of serum or ultrafiltrate of serum plus raffinose was perfused (Table I, top and middle) was calculated as:

$$
P_{\mathrm{Na}_{b} \rightarrow 1}=\frac{\mathrm{M}_{\mathrm{Na}_{1 \rightarrow b}}-\mathrm{M}_{\mathrm{Na}}}{[\mathrm{Na}]_{\mathrm{b}}}
$$

and in experiments in which raffinose solution was perfused as

$$
P_{\mathrm{Na}_{b \rightarrow 1}}=\frac{\left[{ }^{24} \mathrm{Na}\right]_{\mathrm{L}}}{\left[{ }^{24} \mathrm{Na}\right]_{\mathrm{b}}} \times \frac{\mathrm{P}_{\mathrm{Na}_{1 \rightarrow b}}}{1-\exp \left[-\left(\mathrm{P}_{\mathrm{Na}_{1 \rightarrow b}} \mathrm{~A}\right) / \mathrm{V}\right]}
$$

where $\mathrm{V}=\left(\mathrm{V}_{\mathrm{O}}+\mathrm{V}_{\mathrm{L}}\right) / 2$ and $\mathrm{P}_{\mathrm{Na}_{1 \rightarrow b}}$ is assumed to equal $14 \times 10^{-6} \mathrm{~cm} \mathrm{sec}^{-1}$, the mean value obtained in experiments with $\mathrm{Na}$ containing perfusion fluids. Actually the precise value of $\mathrm{P}_{\mathrm{Na}_{1 \rightarrow b}}$ employed in this calculation makes relatively little difference, since for the worst case (slowest perfusion rate) a $50 \%$ underestimate of $\mathrm{P}_{\mathrm{Na}_{1 \rightarrow b}}$ yields only a $12 \%$ overestimate of $\mathrm{P}_{\mathrm{Nab} \rightarrow 1}$.

The length of the tubule (L) was measured with an ocular micrometer. Luminal area (A) was calculated from L, assuming a diameter of $20 \mu$. The arbitrary diameter of $20 \mu$ was chosen in order to facilitate comparison with other tubule studies in which this figure has generally been used.

Results are expressed as mean ISEM (number of tubules studied). The data for each tubule are the mean of the results of two or three collection periods under a given set of conditions.

\section{RESULTS}

An approximation of the conditions which exist in vivo was obtained by bathing the proximal tubule in rabbit serum and perfusing it with an ultrafiltrate of the same serum. Net fluid absorption was measured under these circumstances in two sets of studies. In the first (five experiments were done) (Table I, upper set) $1.24 \pm 0.30$ $\mathrm{nl} \mathrm{mm}^{-1}$ tubule length $\mathrm{min}^{-1}\left(3.41 \times 10^{-5} \mathrm{~cm}^{3} \mathrm{~cm}^{-2}\right.$ luminal area $\sec ^{-1}$ ) was absorbed, and in the second

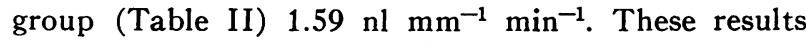
are in reasonable agreement with those published previously from this laboratory (4). In addition, as in rat (1), $\operatorname{dog}(9)$, and monkey (10) in vivo, $\mathrm{Na}$ is reabsorbed isotonically, i.e. without a change in the concentration of $[\mathrm{Na}]$ in the luminal fluid. As can be seen in Table I (upper set), the concentration of $\mathrm{Na}$ in collected fluid was 145 mmoles liter ${ }^{-1}$, that in the ultrafiltrate per-

TABLE II

Measurement of Reflection Coefficient for $\mathrm{NaCl}\left(\sigma_{\mathrm{NaCl}}\right)$ in Isolated Perfused Rabbit Proximal Convoluted Tubules

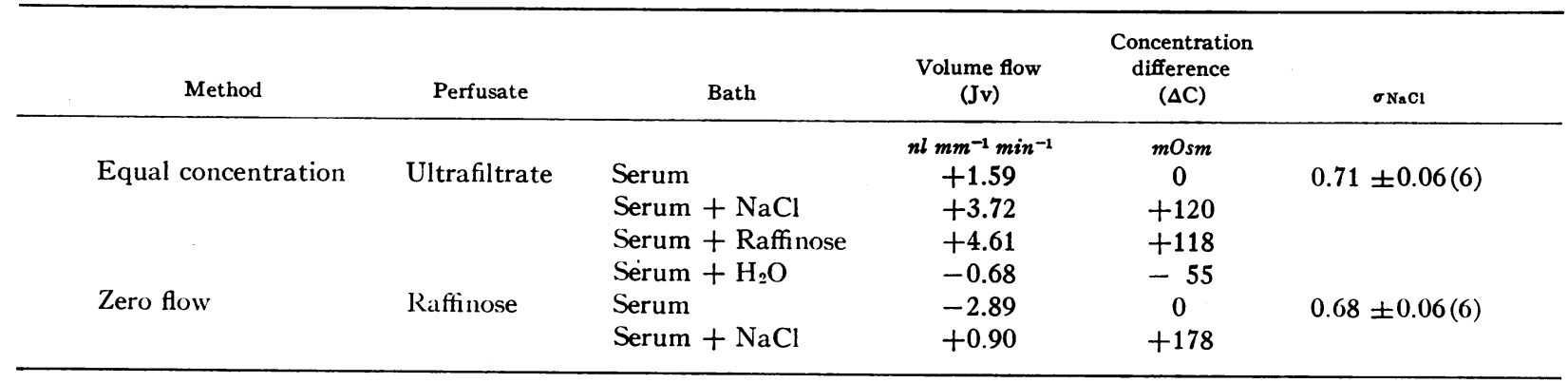




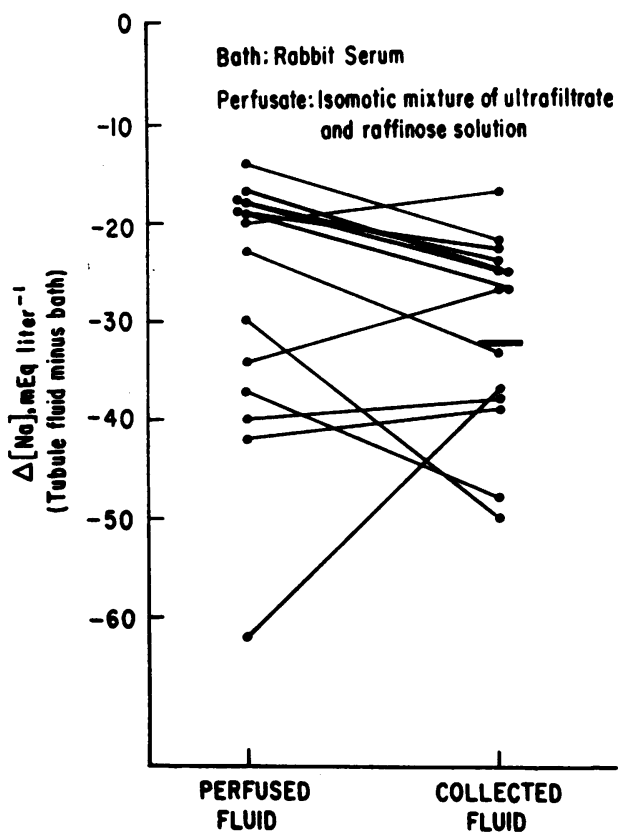

Figure 1 Steady-state concentration difference for $\mathrm{Na}$ in isolated perfused proximal convoluted tubules. Bath was rabbit serum; perfusate was an isosmotic mixture of ultrafiltrate and raffinose solution. Mean concentration difference in collected fluid ( $33 \mathrm{mEqL}$ liter $\left.^{-1}\right)$ is assumed to be equal to the mean steady-state value under these conditions.

fused 146 mmoles liter $^{-1}$. The mean net flux of $\mathrm{Na}$ in the same studies (five experiments) was $4.46 \times 10^{-9} \pm 0.47$

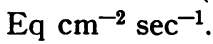

Reabsorption of $\mathrm{NaCl}$ without its complement of water occurs in vivo when a poorly absorbable solute such as mannitol is added in isosmotic proportions to the proximal fluid (11). The osmotically active solute restricts the efflux of water which in the absence of mannitol, for example, is coupled osmotically with net $\mathrm{NaCl}$ absorption. Continuing net $\mathrm{NaCl}$ absorption results in a fall in the concentration of $\mathrm{Na}$ in the luminal fluid until a limiting gradient across the cell is reached, at which time net movement of both water and $\mathrm{Na}$ virtually ceases. In the rat limiting or steady-state concentration of $\mathrm{Na}$ in the lumen has been found to be $35 \mathrm{mEq}$ liter $^{-1}$ less than that in plasma $(12,13)$.

The steady-state concentration difference for $\mathrm{Na}$ across the isolated perfused rabbit proximal tubule was determined in a series of studies in which the tubules were perfused at slow rates $\left(1-5 \mathrm{nl} \mathrm{min}{ }^{-1}\right)$ with isosmotic solutions composed of an ultrafiltrate of serum mixed in varying proportions with an isosmolar raffinose solution. The results are illustrated in Fig. 1. It is apparent that despite differences in the initial $\mathrm{Na}$ concentration of the perfusate which varied between 14 and $62 \mathrm{mEq}$ liter $^{-1}$ less than in the bath, the mean concentration of $\mathrm{Na}$ in the collected perfusion fluid was $33 \mathrm{mEq}$ liter $^{-1}$ less than in the bath. It is reasonable to conclude that the latter figure represents the mean limiting or steadystate concentration difference since in eight of nine tubules in which the initial concentration difference of $\mathrm{Na}$ was less than $33 \mathrm{mEq}$ liter $^{-1}$ it increased, and in four of five in which the initial difference was greater it decreased. In another series of studies performed at more rapid perfusion rates (Table I, middle set) the $\mathrm{Na}$ concentration of the perfusate was $31 \mathrm{mEq}$ liter $^{-1}$ less than that of the bath, and the mean difference between collected tubule fluid and bath was $35 \mathrm{mEq} \mathrm{liter}{ }^{-1}$.

Net $\mathrm{Na}$ flux $\left(\mathrm{M}_{\mathrm{Na}}\right)$, unidirectional $\mathrm{Na}$ flux from lumen to bath $\left(\mathrm{M}_{\mathrm{Na} \mathbf{1}_{1 \rightarrow b}}\right)$ and the permeability of $\mathrm{Na}$ of the tubule from bath to lumen $\left(\mathrm{P}_{\mathrm{Nab} \rightarrow 1}\right)$ were measured under the following three sets of experimental conditions: (a) during perfusion of tubules bathed in rabbit serum with an ultrafiltrate of serum, the condition which most closely resembles the in vivo physiologic state; (b) during perfusion with an isosmolal mixture of raffinose and ultrafiltrate of serum of tubules bathed in serum (the $\mathrm{Na}$ concentration difference between the perfusion solution and the bath approximated the steady-state concentration difference obtained in the studies described above [Fig. 2]); and (c) during perfusion with a $\mathrm{Na}$-free raffinose solution (isosmotic to normal serum) of tubules bathed in rabbit serum to which sufficient $\mathrm{NaCl}$ was added to minimize osmotic flow of water into the lumen (v.i.). Under these circumstances $\mathrm{Na}$ which enters the lumen from the bath must be accompanied by anion, presumably chloride so that the permeability measured is that of the tubule to the $\mathrm{Na}$ salt (principally $\mathrm{NaCl}$ ), rather than to $\mathrm{Na}$ alone. Any contribution of either exchange diffusion or forced exchange of $\mathrm{Na}$ with another cation is excluded.

In the first series of studies (Table I, upper set), as indicated above, net fluid absorption occurred without

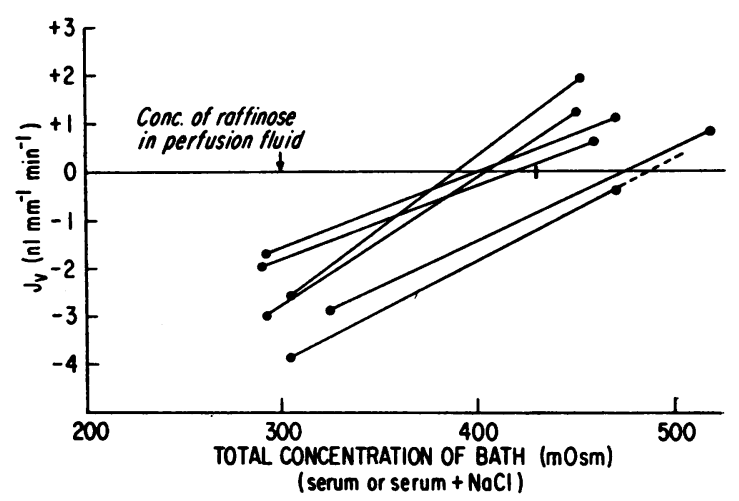

Figure 2 Measurement of reflection coefficient for $\mathrm{NaCl}$ $\left(\sigma_{\mathrm{NaCl}}\right)$ in isolated perfused rabbit proximal convoluted tubule by the zero flow method. Perfusate was raffinose solution whose mean concentration ( $298 \mathrm{mOsm})$ is indicated by the arrow. Mean concentration of bath for zero flow $\left(J_{v}=0\right)$ was 435 mOsm. Thus, $\sigma_{\mathrm{NaCl}}=298 / 435=0.68$. 
a change in the $\mathrm{Na}$ concentration of the perfusate. The mean net flux, $\mathrm{M}_{\mathrm{Na}}$, was $4.46 \times 10^{-9} \mathrm{Eq} \mathrm{cm} \mathrm{cm}^{-2} \mathrm{sec}^{-1}$. This was approximately $20 \%$ of the unidirectional flux of $\mathrm{Na}$ from lumen to bath $\left(\mathrm{M}_{\mathrm{Na} 1 \rightarrow \mathrm{b}}=20.0 \times 10^{-9} \mathrm{Eq}\right.$ $\mathrm{cm}^{-2} \mathrm{sec}^{-1}$ ). The mean permeability of the tubule to $\mathrm{Na}$ from bath to lumen was $10.2 \times 10^{-5} \mathrm{~cm} \mathrm{sec}^{-1}$.

The second set of studies (Table I, middle set) was designed to measure the unidirectional $\mathrm{Na}$ flux from lumen to bath $\left(\mathrm{M}_{\mathrm{Na}_{1 \rightarrow b} \mathrm{~b}}\right)$ and the permeability to $\mathrm{Na}$ from bath to lumen $\left(\mathrm{P}_{\mathrm{Nab}_{b} \rightarrow 1}\right)$ in the steady state, i.e. in the absence of net $\mathrm{Na}$ and $\mathrm{H}_{2} \mathrm{O}$ movement, in order to minimize the effect of solute and water interactions on the fluxes. Although on the average this state was approached, significant net fluxes occurred in individual studies. It is uncertain whether this represents functional variation between tubules or is a reflection of the difficulty of measuring with precision net water flux at high rates of perfusion. ${ }^{2}$ The mean $\mathrm{Na}$ permeability from bath to lumen was $9.3 \times 10^{-5} \mathrm{~cm} \mathrm{sec}^{-1}$ which is not significantly different from the result obtained in the experiments in which the perfusate was ultrafiltrate alone.

In the third series of experiments (Table J, lower set) net flux of water into the 312 milliosmolal raffinose perfusion solution was virtually eliminated (on the average) by increasing the osmolality of serum in the bath to $439 \mathrm{mOsm}$ by the addition of $\mathrm{NaCl}$. Under these conditions the mean $\mathrm{Na}$ permeability from bath to lumen (which must equal the permeability to $\mathrm{NaCl}$, v.s.) was $7.0 \times 10^{-5} \mathrm{~cm} \mathrm{sec}^{-1}$. This result cannot be interpreted with certainty without knowledge of the electrical potential difference. The relatively small difference in the $\mathrm{Na}$ permeability with and without $\mathrm{Na}$ salts in the lumen however is consistent with lack of important interaction between the $\mathrm{Na}$ fluxes in the two directions such as would occur were exchange diffusion or single file diffusion a major mechanism for $\mathrm{Na}$ permeation in the tubule. Baumann, Frömter, and Ullrich (14) obtained a different result (when comparing $\mathrm{Na}$ to $\mathrm{NaCl}$ flux) in rat proximal convoluted tubules perfused in vivo. The permeability measured from the appearance of $\mathrm{Na}$ in raffinose solution perfused through the tubule lumen $\left(36-89 \times 10^{-5} \mathrm{~cm} \mathrm{sec}^{-1}\right)$ was greater than the isotonic $\mathrm{Na}$ permeability $\left(25 \times 10^{-5} \mathrm{~cm} \mathrm{sec}^{-1}\right)$ measured with $\mathrm{NaCl}$ in the lumen rather than less, as in the present studies. The reason for this difference is unclear at present.

Certain solutes fail to exert the full osmotic effect predicted from the van't Hoff relationship $(\pi=n R T \Delta C$, where $\pi=$ osmotic pressure and $n, R, T$ have their usual meanings, and $\Delta \mathrm{C}=$ difference in concentration

${ }^{2}$ With a flow rate of $20 \mathrm{nl} \mathrm{min}-1$ (333 $\left.\times 10^{-9} \mathrm{~cm}^{3} \mathrm{sec}^{-1}\right)$ through a tubule $1 \mathrm{~mm}$ long a $5 \%$ error in the concentration of albumin results in difference of $1 \mathrm{nl} \mathrm{mm} \mathrm{mm}^{-1} \mathrm{~min}^{-1}(2.66 \mathrm{~cm}$ $\left.\sec ^{-1} \times 10^{-6}\right)$ in the estimation of net fluid flux across the membrane) on water flow across artificial and biological membranes. Staverman (15) correctly interpreted this to indicate penetration of the solute through the membrane and defined the fractional deviation from the van't Hoff pressure, $\sigma$, or reflection coefficient, as the ratio of the experimentally observed $\pi$ to the calculated $\pi$. Subsequently the importance of the reflection coefficient for defining the properties of biological membranes has been emphasized (16). At least two experimental techniques, the "zero flow" and "equal concentration" methods, have been devised to measure $\sigma$ (17). In both the effect of a test solute is compared with that of an impermeant reference solute. In the zero flow method the test solute is placed on one side of the membrane and the reference solute on the other. The ratio of the solute concentration (reference/ test) at which zero net flow occurs is equal to $\sigma$. In the equal concentration method the increment in osmotic flow induced by equal concentrations of test and reference solutes across a membrane are compared. The reflection coefficient is the ratio of the increment in flow induced by the test solute to that induced by the reference solute. Precision in the determination of $\sigma$ is limited in consequence of movement of the test solute or water across the membrane which thereby alters the osmotic gradient. Modifications of both methods have been used in the present studies to determine the reflection coefficient of the rabbit proximal tubule for $\mathrm{NaCl}$ $\left(\sigma_{\mathrm{NaCl}}\right)$. The data are illustrated in Table II and Fig. 2.

The concentration of $\mathrm{NaCl}$ in the bath necessary to counterbalance the osmotic effect of $300 \mathrm{mOsm}$ raffinose in the perfusion solution (zero flow method) was determined as follows. The tubule was first bathed in normal serum and perfused with a raffinose solution. As can be seen in Table II, a mean of $2.89 \mathrm{nl} \mathrm{mm}^{-1} \mathrm{~min}^{-1}$ of fluid moved into the tubule lumen. Following this, $\mathrm{NaCl}$ was added to the bathing solution to achieve a final osmolality approximately $178 \mathrm{mOsm}$ greater than that of the perfusate. Under these circumstances the direction of flow reversed; the mean absorption from the lumen was $0.90 \mathrm{nl} \mathrm{mm}^{-1} \mathrm{~min}^{-1}$. The sequence of the procedure was reversed in some studies, and the individual data are illustrated in Fig. 2. The osmolality of the bath (or the concentration of $\mathrm{NaCl}$ ) at which no net flow occurred was determined by extrapolation, and $\sigma_{\mathrm{NaCl}}$ was calculated as above. The mean reflection coefficient was $0.68 \pm 0.06$ (6).

The reflection coefficient of 0.68 is an imprecise estimate for two reasons. In the first place, $\mathrm{NaCl}$ entered the lumen in the course of the study, thereby reducing the concentration gradient below that used in the calculation. The mean concentration of $\mathrm{Na}$ in the collected fluid was 26 and $40 \mathrm{mEq}$ liter $^{-1}$ when the tubule was bathed in isosmotic and hyperosmotic sera, respectively. Were this taken into account the $\sigma$ would 
be approximately $10 \%$ higher. In addition flow across biological membranes is not necessarily a linear function of the osmotic gradient, so that the linear extrapolation used in Fig. 2 may be in error. The error so introduced is probably of negligible significance since net flow approximated zero when the bath was hypertonic. Bauman, Frömter, and Ullrich (14) estimated $\sigma_{\mathrm{NaCl}}$ of the rat proximal convoluted tubule in vivo by determining the concentration of raffinose in the perfusate necessary to eliminate net water flow, and they obtained the same result $(0.69)$ as did we.

The reflection coefficient was also determined in a second set of studies in which a modification of the equal concentration method was used. The data are presented in Table II. In these experiments in order to minimize changes in the $\mathrm{NaCl}$ concentration of the perfusate short segments of tubules $(1.2 \mathrm{~mm}$ mean length) were perfused rapidly $\left(25 \mathrm{nl} \mathrm{min}^{-1}\right)$ with an ultrafiltrate of rabbit serum and the absorptive rate measured. The increment in net absorption induced by the addition of $120 \mathrm{mOsm}$ of $\mathrm{NaCl}$ to the bathing serum was compared with that induced by $118 \mathrm{mOsm}$ of raffinose and $\sigma_{\mathrm{NaCl}}$ calculated as discussed above. In each of the six studies two measurements of absorption with normal serum in the bath were made at the beginning and end of the experiment. Since there were no significant differences observed between the early and late periods, the data from the four periods were pooled to calculate the mean rate of fluid absorption $\left(\mathrm{J}_{\mathrm{v}}\right)$ without an osmotic gradient. The mean of three periods each with either raffinose or $\mathrm{NaCl}$ added to the bath was used to calculate the respective increments in absorptive rate (osmotic flows). The order of additions was varied appropriately. Using this procedure the mean reflection coefficient was $0.71 \pm 0.06(6)$. This value is also subject to errors introduced by alteration in the composition of the perfusate which cannot be avoided. In this regard it is of some interest that we observed as did Ullrich, Rumrich, and Fuchs in the rat (18) that the osmolality of the collected raffinose solution (mean $335 \mathrm{mOsm}$ ) rises above that of bathing serum (mean 306 mOsm) despite net flow of fluid into the tubule lumen. Apparently the permeability of the proximal tubule to $\mathrm{Na}$ is so great that relatively more $\mathrm{Na}$ salts enter the lumen by diffusion and perhaps by solvent drag than does water by osmosis.

The hydraulic conductivity $\left(L_{p}\right)$ of the tubule to water was also estimated from the results of the studies in Table II. The estimated values and the experimental conditions are listed in Table III. Since these are the same data as were used to determine $\sigma_{\mathrm{NaCl}}$, the calculated values of $L_{p}$ are subject to the same uncertainties as are those for $\sigma_{\mathrm{NaCl}}$ and must be regarded as approximations.
TABLE III

Measurement of Water Permeability (Hydraulic Conductivity, $\left.L_{P}\right)$ in Rabbit Proximal Convoluted Tubule

\begin{tabular}{|c|c|c|c|}
\hline Lumen & Bath & $\begin{array}{c}\text { Concentration } \\
\text { difference } \\
(\Delta \mathrm{C})\end{array}$ & $L_{P}$ \\
\hline & & $m O s m$ & $\begin{array}{l}\left(\mathrm{cm}^{3} \mathrm{~cm}^{-2} \mathrm{sec}^{-1}\right. \\
\left.\mathrm{atm}^{-1} \times 10^{-5}\right)\end{array}$ \\
\hline Ultrafiltrate & Serum + raffinose & +117 & $2.9 \pm 0.2(7)$ \\
\hline Raffinose & Serum & 0 & $3.7 \pm 0.4(6)$ \\
\hline Ultrafiltrate & Serum + water & -55 & $6.3 \pm 0.7(7)$ \\
\hline
\end{tabular}

Three different values of $L_{p}$ obtained under separate experimental conditions were calculated.

The first calculation was based on the results of the studies (Table III) in which the driving force for water movement was the osmotic pressure due to $117 \mathrm{~mm}$ raffinose added to the serum in the bath. Net flow of water was therefore out of the lumen. Under these circumstances

$$
\mathrm{L}_{\mathrm{p}}=\frac{\Delta \mathrm{J}_{\mathbf{v}}}{\mathrm{RT} \mathrm{C}_{\mathrm{rafinose}}}
$$

where $\Delta \mathrm{J}_{\mathrm{v}}=$ the increment in net flow of water per unit surface area per unit time induced by the increase in osmolality due to raffinose $\left(\mathrm{C}_{\text {raffinose }}\right)$ and $\mathrm{R}$ and $\mathrm{T}$ have the usual significance. Raffinose, as in the studies described earlier, is assumed to have a $\sigma$ of 1 . The mean $\mathrm{L}_{\mathrm{p}}=2.9 \times 10^{-5} \mathrm{~cm} \mathrm{sec}^{-1} \mathrm{~atm}^{-1}$.

In the second series of studies with raffinose as the perfusion solution and serum in the bath net water flow is into the lumen.

$$
\mathrm{L}_{\mathrm{p}}=\frac{\mathrm{J}_{\mathrm{v}}}{\mathrm{RT}\left(\mathrm{C}_{\mathrm{raffinoye}}-\sigma_{\mathrm{NaCl}}\left[\mathrm{C}_{\mathrm{Nab}}-\mathrm{C}_{\mathrm{NaL}} / 2\right]\right)}
$$

where $\mathrm{J}_{\mathrm{v}}=$ the rate of net water flow per unit membrane area per unit time and $\left[\mathrm{C}_{\mathrm{Na}}-\mathrm{C}_{\mathrm{NaL}} / 2\right]$ is the mean concentration difference in mOsm liter ${ }^{-1}$ of $\mathrm{Na}$ between the bath and lumen. The mean $\mathrm{L}_{\mathrm{p}}=3.7 \times 10^{-5}$ $\mathrm{cm} \mathrm{sec}^{-1} \mathrm{~atm}^{-1}$.

In the third set of the studies (Tables II and III) water was added to the serum in the bathing solution to lower the osmolality $55 \mathrm{mOsm}$ below that of the ultrafiltrate in the lumen. Net flow into the bath diminished and in some studies reversed.

$$
\mathrm{L}_{\mathrm{p}}=\frac{\Delta \mathrm{J}_{\mathrm{v}}}{\mathrm{RT} \sigma_{\mathrm{NaCl}} \Delta \mathrm{C}}
$$

where $\Delta \mathrm{C}=-55 \mathrm{mOsm}$. The mean value of $\mathrm{L}_{\mathrm{p}}=6.3$ $\times 10^{-5} \mathrm{~cm} \mathrm{sec}^{-1} \mathrm{~atm}^{-1}$.

The hydraulic conductivity of the rat proximal convoluted tubule in vivo was found to be $17 \times 10^{-5}$ $\mathrm{cm} \mathrm{sec}^{-1} \mathrm{~atm}^{-1}$ (14).

It is noteworthy that $L_{p}$ was highest in the current studies when the osmolality of the bathing solution was 
lowest, and lowest when the osmolality was highest. This result is analogous to that observed in the rat proximal tubule (14) and in other tissues (19).

\section{DISCUSSION}

The results of the present studies are in many respects similar to those previously obtained in in vivo micropuncture studies in other species. This of itself is gratifying and indicative of the utility of the in vitro preparation. The isolated perfused proximal convoluted tubule of the rabbit is highly permeable to $\mathrm{NaCl}$ and water and actively transports an isosmotic solution out of the lumen. As in the nephron in vivo no change in the concentration of $\mathrm{Na}$ occurs during reabsorption unless a relatively nonabsorbable solute such as raffinose is present in the perfusate. In the latter case the concentration of $\mathrm{Na}$ declines and reaches a minimum steady-state value $30-35 \mathrm{mEq} \operatorname{liter}^{-1}$ less than in the bath.

This steady-state concentration difference, virtually identical with that reported in rat $(12,13)$, is achieved when the rate of active efflux of $\mathrm{Na}$ from the lumen is equal to the rate of net passive backflux from the bath to the lumen. In the present studies net backflux of $\mathrm{Na}$ at the steady-state minimum luminal concentration was determined from the relationship $\mathrm{M}_{\mathrm{Nab} \rightarrow 1}=\mathrm{P}_{\mathrm{Nab} \rightarrow 1}$ $\times \Delta \mathrm{C}_{\mathrm{Na}}$, where $\mathrm{M}_{\mathrm{Nab} \rightarrow 1}$ is net backflux of $\mathrm{Na}, \mathrm{P}_{\mathrm{Na}_{\mathrm{b} \rightarrow 1}}$ the isotopic $\mathrm{Na}$ permeability from bath to lumen, and $\Delta \mathrm{C}_{\mathrm{Na}}$ the steady-state concentration difference between bath and lumen (33 $\mathrm{mEq}$ liter $\left.{ }^{-1}\right)$. Then, $\mathrm{M}_{\mathrm{Nab} \rightarrow 1}$ $=3.13 \times 10^{-9}$ moles $\mathrm{cm}^{-2} \mathrm{sec}^{-1}$.

This value, assumed to be equal to the rate of active transport of $\mathrm{Na}$ in the steady state with raffinose in the perfusate may be compared with the net flux of sodium out of tubules bathed in rabbit serum and perfused with an ultrafiltrate of the same serum. The net flux, equal to the rate of active $\mathrm{Na}$ transport out of the tubule under these circumstances, was $4.46 \times 10^{-9}$ moles $\mathrm{cm}^{-2} \mathrm{sec}^{-1}$ or approximately $40 \%$ higher than with raffinose added to the perfusate. Ullrich (20), on the basis of similar calculations, reported that active transport of $\mathrm{Na}$ with raffinose added to the perfusate $\left(\Delta \mathrm{C}_{\mathrm{Na}}=35 \mathrm{mEq} \mathrm{liter}{ }^{-1}\right)$ was $9.8 \times 10^{-9}$ moles $\mathrm{cm}^{-2}$ $\mathrm{sec}^{-1}$ and was $9.0 \times 10^{-9}$ moles $\mathrm{cm}^{-2} \mathrm{sec}^{-1}$ in the absence of a concentration difference for $\mathrm{Na}$. He concluded that the $\mathrm{Na}$ transport mechanism was saturated under both circumstances (13). Although our results are at variance with his and if accepted at face value would lead to the opposite conclusion, we are not convinced of the validity of the calculations. The rate of active transport with poorly absorbable solute in the lumen is probably an underestimate for two reasons. In the first place the calculation is dependent upon the assumption that there is no electrical driving force (transtubular PD) in the steady state which may not be correct. Were there a negative $\mathrm{PD}$ as there is in the rabbit proximal tubule during isosmotic net transport (mean of -3.8 , mv lumen negative, with rabbit serum in the bath and ultrafiltrate in the perfusion fluid [21]), net passive flux into the tubule would be greater than that calculated above. Secondly, net $\mathrm{NaCl}$ absorption, albeit at a markedly reduced rate, occurs in the rat in the steady state with raffinose (22) and were this the case in the rabbit as it appears to be (Table I, middle), the calculated rate of active $\mathrm{Na}$ transport would again be an underestimate.

In any event, it is of interest that the rat proximal tubule actively transports $\mathrm{Na}$ two to three times as rapidly as does that of the rabbit and also is two to three times as permeable to $\mathrm{Na}$. Since the steady-state concentration difference for $\mathrm{Na}$ depends on the ratio of active transport to passive permeability, the equality of this ratio in the two species readily accounts for the virtual identity of the $\mathrm{Na}$ concentration differences in the presence of raffinose in rat and rabbit. On the basis of these observations, it is suggested that the transport mechanisms may be basically the same in rat and rabbit but that the tubule of the former species contains more transport units and passive permeability paths per unit length than does that of the rabbit. Consistent with this view is the observation that the reflection coefficient for $\mathrm{Na}$, which like the steady-state concentration difference is independent of area, is the same in rat and rabbit, whereas the $\mathrm{L}_{p}$ and $\mathrm{Na}$ permeability which are functions of surface area are greater in the rat.

\section{REFERENCES}

1. Walker, A. M., P. A. Bott, J. Oliver, and M. C. MacDowell. 1941. The collection and analysis of fluid from single nephrons of the mammalian kidney. Amer. $J$. Physiol. 134: 580 .

2. Windhager, E. E., and G. Giebisch. 1965. Electrophysiology of the nephron. Physiol. Rev. 45: 214.

3. Burg, M., J. Grantham, M. Abramow, and J. Orloff. 1966. Preparation and study of fragments of single rabbit nephrons. Amer. J. Physiol. 210: 1293.

4. Burg, M. B., and J. Orloff. 1968. Control of fluid absorption in the renal proximal tubule. J. Clin. Invest. 47: 2016.

5. Burg, M., S. Helman, J. Grantham, and J. Orloff. 1970. Effect of vasopressin on the permeability of isolated rabbit cortical collecting tubules to urea, acetamide, and thiourea. In Urea and the Kidney. B. Schmidt-Nielsen and D. W. S. Kerr, editors. Exerpta Medica Foundation, Amsterdam. 193.

6. Burg, M. B., and J. Orloff. 1966. Effect of temperature and medium $\mathrm{K}$ on $\mathrm{Na}$ and $\mathrm{K}$ fluxes in separated renal tubules. Amer. J. Physiol. 211: 1005.

7. Ramsay, J. A., and R. H. J. Brown. 1955. Simplified apparatus and procedure for freezing-point determinations upon small volumes of fluid. J. Sci. Instrum. 32: 372.

8. Grantham, J. J., and M. B. Burg. 1966. Effect of vasopressin and cyclic AMP on permeability of isolated collecting tubules. Amer. J. Physiol. 211: 255. 
9. Bennett, C. M., J. R. Clapp, and R. W. Berliner. 1967. Micropuncture study of the proximal and distal tubule in the dog. Amer. J. Physiol. 213: 1254.

10. Bennett, C. M., B. M. Brenner, and R. W. Berliner. 1968. Micropuncture study of nephron function in the rhesus monkey. J. Clin. Invest. 47: 203.

11. Windhager, E. E., and G. Giebisch. 1961. Micropuncture study of renal tubular transfer of sodium chloride in the rat. Amer. J. Physiol. 200: 581.

12. Kashgarian, M., H. Stöckle, C. W. Gottschalk, and K. J Ullrich. 1963. Transtubular electrochemical potentials of sodium and chloride in proximal and distal renal tubules of rats during antidiuresis and water diuresis (diabetes insipidus). Pfluegers Arch. 277: 89.

13. Baldamus, C. A., K. Hierholzer, G. Rumrich, H. Stolte, E. Uhlich, K. J. Ullrich, and M. Wiederholt. 1969. Natrium transport in den proximalen Tubuli und den Sammelrohren bei Variation der Natrium konzentration im umgebenden Interstitium. Pfluegers Arch. 310: 354.

14. Bauman, K., E. Frömter, and K. Ullrich. 1967. Passiver Stofftransport durch Epithelzellschicht von Harnkanälchen. Berichte der Bunsenges. Phys. Chem. 71: 834.

15. Staverman, A. J. 1951. The theory of measurement of osmotic pressure. Rec. Trav. Chim. Pays-Bas 70: 344 .
16. Kedem, O., and A. Katchalsky. 1958. Thermodynamic analysis of the permeability of biological membranes to non-electrolytes. Biochim. Biophys. Acta $27: 229$.

17. Wright, E. M., and J. M. Diamond. 1969. An electrical method of measuring nonelectrolyte permeability. Proc. Roy. Soc. Ser. B. Biol Sci. 172: 203.

18. Ullrich, K. J., G. Rumrich, and G. Fuchs. 1964. Wasserpermeabilität und transtubulärer Wasserfluss corticaler Nephronabschnitte bei verschiedenen Diuresezuständen. Pfluegers Arch. 280: 99.

19. Diamond, J. M. 1966. Non-linear osmosis. J. Physiol. (London). 183: 58.

20. Ullrich, K. J. 1967. Renal transport of sodium. Proceedings of the 3rd International Congress of Nephrology, Washington, D. C. 1: 48 .

21. Burg, M., and J. Orloff. 1970. Electrical potential difference across proximal convoluted tubules. Amer. J. Physiol. In press.

22. Gertz, K. H. 1963. Transtubuläre Natriumchoridflusse und Permeabilität für Nichtelektrolyte im proximalen und distalen Konvolut der Rattenniere. Pfluegers Arch. 276: 336. 